\title{
BIOSTRATIGRAPHIC EXPRESSION OF AN UPPER CRETACEOUS MAXIMUM FLOODING SURFACE IN THE TECTONICALLY OVERPRINTED CENTRAL COAST RANGES
}

SILK*, Michelle T., Museum of Paleontology, University of California, Berkeley CA 94720; JONES, Davy L., Department of Geology, University of California, Berkeley CA 94720, U.S.A.

Variations in radiolarian abundance and diversity data can be used to define condensed sections in deep-marginal environments, and hence have several important implications for both sequence stratigraphic and tectonic analysis. As both analytical techniques clearly are independent of temporal and spatial considerations, radiolaria provide a time stratigraphic framework for interpreting and predicting cyclic, lithologic successions. They also are the biostratigraphic expression of maximum flooding surfaces, which, while not true sequence boundaries, can be indicative of post-relative sea-level low stand. Periods of late low stand and early transgression are often characterized by sediment bypass over shelves and basinward fan development. Radiolarian faunas can often be recovered from lower fan, distal turbidites and/or deepbasin deposits, and characteristic assemblages can be subdivided into proximal and distal biofacies. Thus, they provide a direct correlative link between the evolution of basin fill and true deep-water deposits.

We propose that sequence stratigraphic analysis of late Cretaceous terrane, subterrane and detached crustal blocks, shuffled and shredded by Neogene tectonic activity along major splays of the San Andreas System in the Central California Coast Ranges, provide detailed clues concerning formation processes and geographic origin.

Radiolarian abundance, diversity and paleobathymetric patterns were determined from nine sites within the Upper Cretaceous (Upper Campanian) Sacramento Shale of the Great Valley sequence. These data were used to assess the radiolarian assemblages and to infer paleoenvironments, for the imbricated thrust sheets responsible for surface expression of the Sacramento Shale. Radiolarian assemblages from this interval, range from total calcareous replacement (proximally) to original biogenic silica (distally). Based on known environmental data, we have divided the Sacramento Shale into three distinct depositional settings: Proximal, distal, and true basinal. Assemblages from these coeval settings consist variably of (1) mineralogically replaced taxa dominated by the Neosciadocapsidae (e.g. Neosciadiocapsa diabloensis) and the Phaseliformidae (e.g. Phaseliforma meganosensis); (2) mineralogically altered siliceous taxa dominated by the Sponguridae (e.g. Archaeospongoprunum hueyi) and Spumellariina Incertae Sedis; and (3) non-replaced opaline siliceous taxa dominated by the Archaeodictyomitridae (e.g. Archaeodictyomitra (?) regina).

Finer scale examination of diversity within each setting may help us to decipher their allochtonous - autochtonous nature, and predict possible biogeographic origins. The Sacramento Shale thus represents part of a larger transgressive systems tract, with evidence of significant facies differentiation, resulting from the diverse origins of the tectonically overprinted crustal blocks. 